\title{
The Influence Of Physical Evidence, Reliability, Responsiveness, Assurance And Empathy To The Consumer Satisfaction Of The KFC Grand Kota Bintang Bekasi
}

\author{
Waseso Segoro ${ }^{1}$, Maria Magdalena Tri Permatasari ${ }^{2 *}$ \\ ${ }^{1,2}$ Faculty of Economics, Gunadarma University, Indonesia \\ *Corresponding Author: \\ Email: magdalenasari1215@gmail.com
}

\begin{abstract}
.
The growing number of fast-food restaurants, which allow businesses to compete with one another to meet their business goals and to provide good quality services so that they can provide individual satisfaction for their consumers. The study was intended to identify the effects of physical evidence, reliability, responsiveness, assurance and empathy to the consumer satisfaction of the KFC Grand Kota Bintang Bekasi.The analysis tools used in this study are validity test, reliability test, normality test, multicollity test, linear regression test, t-test (partial trials), f-test (simultaneous tests) and coefficiencies tests using version SPSS22. The data used is primary data collected through the questionnaires' method of disseminating the 100 consumer KFC Grand Kota Bintang Bekasi.Research suggests that partial evidence, reliability responsiveness can significantly affect consumer satisfaction while partial assurance and empathy do not significantly affect consumer satisfaction. And simultaneously physical evidence, reliability, responsiveness, assurance and empathy affect significantly the consumer satisfaction of the KFC Grand Kota Bintang Bekasi.
\end{abstract}

Keywords: physical evidence, reliability, responsiveness, assurance, empathy, consumer satisfaction

\section{INTRODUCTION}

Today there are many fast food houses that become the lifestyle of modern society. Because these fast foods are highly practical and varied. In Indonesia, many fast food outlets are keenly interested in consumer goods as well as in surveys conducted by top brand index in fast food restaurants.

\section{Survey Top Brand Index}

Table 1. The $2017-2019$ fast food category

\begin{tabular}{|l|l|l|l|l|l|l|}
\hline \multirow{2}{*}{ BRAND } & \multicolumn{2}{|l|}{$\mathbf{2 0 1 7}$} & \multicolumn{2}{l|}{$\mathbf{2 0 1 8}$} & $\mathbf{2 0 1 9}$ & \\
\cline { 2 - 7 } & TBI & TOP & TBI & TOP & TBI & TOP \\
\hline \multirow{2}{*}{ KFC } & $60.4 \%$ & TOP & $42.7 \%$ & TOP & $26.2 \%$ & TOP \\
\hline MC Donald's & $19.0 \%$ & TOP & $24.3 \%$ & TOP & $22.4 \%$ & TOP \\
\hline A \& W & $3.7 \%$ & & $6.3 \%$ & & $5.4 \%$ & \\
\hline Hoka Hoka Bento & $2.9 \%$ & & $5.8 \%$ & & $5.4 \%$ & \\
\hline CFC & $2.7 \%$ & & - & & - & \\
\hline Richeese Factory & - & & $2.7 \%$ & & $4.3 \%$ & \\
\hline
\end{tabular}

Source: www. Topbrand-award.com 2020 (accessible in 02 May 2020)

Based on the top brand table above the index it is known that over the last three years KFC has a top brand index with its initial number it proves that KFC is known to many people more than any other fast food restaurant. KFC has multiple branches spread across Indonesia, one of its branches in Bekasi city, the KFCGrandKota Bintang Bekasi, which has a strategic location and has a relatively loyal customer. 
Data of visitors to the KFC Grand Kota Bintang Bekasi

Table 2. Period of January to December 2019

\begin{tabular}{|l|l|l|l|l|}
\hline \multirow{2}{*}{ No } & \multicolumn{4}{|l}{ Visitor to the KFC Grand Kota Bintang Bekasi } \\
\cline { 2 - 5 } & Month & Total & Changes & Inf \\
\hline 1 & January & 19.342 & - & - \\
\hline 2 & February & 18.367 & -975 & Down \\
\hline 3 & March & 21.378 & +3.011 & Up \\
\hline 4 & April & 20.586 & -792 & Down \\
\hline 5 & May & 24.783 & +4.197 & Up \\
\hline 6 & June & 21.682 & -3.101 & Up \\
\hline 7 & July & 20.452 & -1.230 & Down \\
\hline 8 & August & 18.679 & -1.773 & Down \\
\hline 9 & September & 20.478 & +1.799 & Up \\
\hline 10 & October & 22.467 & +1.989 & Up \\
\hline 11 & November & 21.347 & -1.120 & Down \\
\hline 12 & December & 25.686 & +4.339 & Up \\
\hline & & & & \\
\hline
\end{tabular}

Source: internal data KFC Grand Kota Bintang Bekasi, 2020

During the one-year period from January to December, there were fluctuations or reductions in visitors. The decline in visitors indicated a decrease in consumer satisfaction with the quality of service. This attracted me to the study of "The effect of physical evidence, reliability, responsiveness, assurance and empathy to the consumer satisfaction of the KFC Grand Kota Bintang Bekasi."

\section{LITERATURE REVIEW}

\section{Physical Evidence}

The company's ability to show its existence to external parties. The appearance and ability of the company's physical tools and infrastructure and its surroundings are tangible evidence of the service rendered (Lupiyoadi, 2006:182).

\section{Reliability}

The ability of a company to give service as accurately as promised(Lupiyaodi 2006:182).

\section{Responsiveness}

A ability to help and provide fast and proper service to consumers with clear information delivery (Lupiyoadi, 2006:182).

\section{Assurance}

Knowledge, courtesy and the ability of company employees to foster a measure of trust in companies (Lupiyoadi, 2006:182).

\section{Empathy}

Giving sincere and individualized or personal attention to consumers by striving to understand the specific physical wants of products or services to appropriate distribution (Lupiyoadi, 2006:182). 


\section{Consumersatisfaction}

(Kotler \& Keller, 2009:177) mentioning consumer satisfaction is the feeling of pleasure or the disappointment of someone who comes from the contrast between his impression of performance (results) of something product with his expectations.

\section{Research Framework}

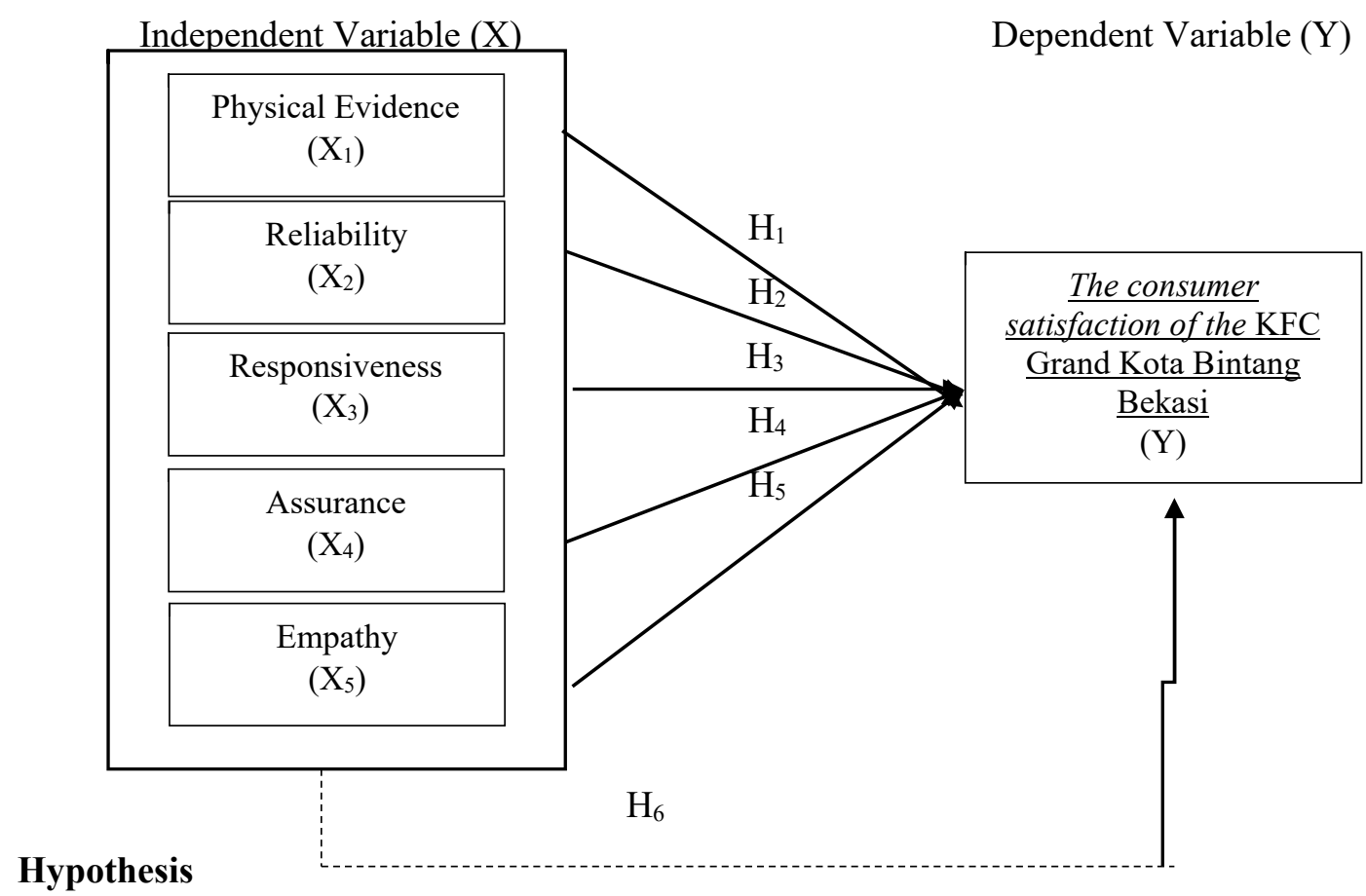

$\mathrm{H}_{1}$ : Physical evidence has a significant impact on consumer satisfaction

$\mathrm{H}_{2}$ : Reliability has a significant impact on consumer satisfaction

$\mathrm{H}_{3}$ : Responsiveness has a significant impact on consumer satisfaction

$\mathrm{H}_{4}$ : Assurance has a significant impact on consumer satisfaction

$\mathrm{H}_{5}$ : Empathy has a significant impact on consumer satisfaction

$\mathrm{H}_{6}$ : Physical Evidence, reliability, responsiveness, assurance and empathy affect consumer satisfaction.

\section{RESEARCH METHOD}

\section{Research Objects}

The object in this study is a consumer who has already visited the KFC Grand Kota Bintang Bekasi system located on KH Noer Ali road, Jakasampurna, west Bekasi, west Java.

\section{Types and Data Sources}

The data used in this study are the primary data. Primary data is data collected directly by researchers form objects to be studied without middlemen. Primary data obtained from a charge of questionnaires sent out to visitors to the KFC Grand Kota Bintang Bekasi.

\section{Research Variable}

Researchers generally measure the truthfulness of a variable and then analyse how one variable relates to another. In the study, there are two such variables as: the free variables used in this study are physical evidence $\left(\mathrm{X}_{1}\right)$, reliability (X2), responsiveness (X3), assurance (X4) a empathy (X5). Whereas the variable is bound to consumer satisfaction $(\mathrm{Y})$.

\section{Population}

The population is all the character that research objects to which these characteristics relate to the entire group of people, events or objects that are central to researchers (Sugiyono, 2011:148).

\section{Sample}

The sample is part or representative of the population to be studied (Arikunto. 2010:172). The sample sampling technique used in this study is non sampling by using the test-sampling technique that 
draws samples from each end of KFC that fit the criteria when researchers conducted research at the KFC Grand Kota Bintang Bekasi so that everyone didn't have the same opportunity to sample.

The size of the population in this study is unknown and vast, this is due to the absence of customer records coming and the large sample used according to Rao Purba (2006) in Kharis (2011) used the following formula.

$$
\mathrm{n}=\frac{Z^{2}}{4(M o e)^{2}}
$$

\section{Description:}

n: sample size

$\mathrm{Z}: 1,96$ score on a certain significance (degree of conviction determined 95\%)

Moe: The maximum fault rate is $10 \%$

The number of samples that can be taken in this study is 100 .

IV. RESULTS AND DISCUSSIONS

\begin{tabular}{|c|c|c|c|}
\hline \multirow{2}{*}{ Hypothesis } & \multicolumn{2}{|l|}{ T Test Results } & \multirow{2}{*}{ Mean } \\
\hline & Statistical Test & Conclusion & \\
\hline $\begin{array}{l}\mathrm{H}_{1} \text { : } \\
\text { Physical } \\
\text { evidence has a } \\
\text { significant } \\
\text { impact on } \\
\text { consumer } \\
\text { satisfaction }\end{array}$ & $\begin{array}{l}\mathrm{t}_{\text {count }}>\mathrm{t}_{\text {table }} \\
(4,914>1,985) \\
\text { Significant levels } \\
(0,000<0,05)\end{array}$ & Influenced & $\begin{array}{l}\text { Based on the t-test, the variable physical } \\
\text { evidence has a positive effect on consumer } \\
\text { satisfaction. The better and more facilities } \\
\text { given by KFC, the greater the consumer } \\
\text { satisfaction. }\end{array}$ \\
\hline $\begin{array}{l}\mathrm{H}_{2}: \text { Reliability } \\
\text { has } \\
\text { significant } \\
\text { impact } \\
\text { consumer } \\
\text { satisfaction }\end{array}$ & $\begin{array}{l}t_{\text {count }}>\mathrm{t}_{\text {table }} \\
(4,617>1,985) \\
\text { Significant levels } \\
(0,000<0,05)\end{array}$ & Influenced & $\begin{array}{l}\text { Based on the t-test, that variables of } \\
\text { reliability have a positive effect on } \\
\text { consumer satisfaction. The appropriate } \\
\text { service factors and the ability of employees } \\
\text { to provide services can make the consumer } \\
\text { feel satisfied with KSC services. }\end{array}$ \\
\hline $\begin{array}{l}\mathrm{H}_{3} \text { : } \\
\text { Responsivenes } \\
\text { s has a } \\
\text { significant } \\
\text { impact on } \\
\text { consumer } \\
\text { satisfaction }\end{array}$ & $\begin{array}{l}\mathrm{t}_{\text {count }}>\mathrm{t}_{\text {table }} \\
(2,380>1,985) \\
\text { Significant levels } \\
(0,019<0,05)\end{array}$ & Influenced & $\begin{array}{l}\text { Based on the t-test, the variable response } \\
\text { has a positive effect on consumer } \\
\text { satisfaction. The faster and more } \\
\text { employees respond to customer service and } \\
\text { consumer satisfaction increases. }\end{array}$ \\
\hline $\begin{array}{l}\mathrm{H}_{4}: \text { Assurance } \\
\text { has } \\
\text { significant } \\
\text { impact } \\
\text { consumer } \\
\text { satisfaction } \\
\end{array}$ & $\begin{array}{l}\mathrm{t}_{\text {count }}<\mathrm{t}_{\text {table }} \\
(-0,501<1,985) \\
\text { Significant levels } \\
(0,618>0,05)\end{array}$ & No Effect & $\begin{array}{l}\text { Based on the t-test suggests that the } \\
\text { collateral variable does not affect consumer } \\
\text { satisfaction. KFC collateral variables do } \\
\text { not create a barrier to consumers will } \\
\text { remain satisfied with the service rendered } \\
\text { by the KFC. }\end{array}$ \\
\hline $\begin{array}{l}\mathrm{H}_{5}: \text { Empathy } \\
\text { has } \\
\text { significant } \\
\text { impact } \\
\text { consumer } \\
\text { satisfaction }\end{array}$ & $\begin{array}{l}\mathrm{t}_{\text {count }}<\mathrm{t}_{\text {tables }} \\
(-0,275<1,985) \\
\text { Significant levels } \\
(0,784>0,05)\end{array}$ & No Effect & $\begin{array}{l}\text { Based on the t-test, the variable empathy } \\
\text { does not affect consumer satisfaction. This } \\
\text { suggests that KFC empathy variables are } \\
\text { not a problem for consumers. The } \\
\text { consumer is well aware of the quality of } \\
\text { the service rendered, so the consumer will } \\
\text { remain satisfied with the service rendered }\end{array}$ \\
\hline \multirow{2}{*}{ Hypothesis } & \multicolumn{2}{|l|}{ F Test Results } & \\
\hline & Statistical Test & Conclusion & \\
\hline
\end{tabular}




\begin{tabular}{|l|l|l|}
\hline $\begin{array}{l}\mathrm{H}_{5:} \\
\text { Physical }\end{array}$ & $\begin{array}{l}\mathrm{F}_{\text {count }}>\mathrm{F}_{\text {table }} \\
(84,395>2,31) \\
\text { Evidence, } \\
\text { reliability, } \\
\text { responsiveness, } \\
\begin{array}{l}\text { assurance and } \\
\text { empathy affect } \\
\text { consumer } \\
\text { satisfaction }\end{array}\end{array}$ & $\begin{array}{l}\text { Variable physical evidence, reliability, } \\
\text { responsiveness, assurance and empathy } \\
\text { affect the consumer satisfaction of the KFC } \\
\text { Grand Kota Bintang Bekasi. In other } \\
\text { words, if KFC was to provide and improve } \\
\text { quality in the service, consumer } \\
\text { satisfaction would be increased. }\end{array}$ \\
\hline
\end{tabular}

\section{CONSLUSION}

Based on analysis and discussion on the effects of physical evidence, reliability, response, assurance and empathy to the consumer satisfaction of the KFC Grand Kota Bintang Bekasi, can be drawn as follows:

1. The physical evidence has a positive and significant impact on the consumer satisfaction of the KFC Grand Kota Bintang Bekasi.

2. The reliability has a positive and significant impact on the consumer satisfaction of the KFC Grand Kota Bintang Bekasi.

3. The responsiveness has a positive and significant impact on the consumer satisfaction of the KFC Grand Kota Bintang Bekasi.

4. The assurance does not affect positive and insignificant consumer satisfaction in the KFC Grand Kota Bintang Bekasi.

5. The empathy does not affect positive and insignificant consumer satisfaction in the KFC Grand Kota Bintang Bekasi.

6. The physical evidence, reliability, responsiveness, assurance and empathy are simultaneously positive and significant to the consumer satisfaction of the KFC Grand Kota Bintang Bekasi.

\section{IMPLICATIONS AND SUGGESTIONS Implications}

1. Variable physical evidence, it is known that physical evidence has an effect on consumer satisfaction. This has the implication that KFC Grand Kota Bintang Bekasi has always to improve the quality of service in the form the physical evidence by maintaining the cleanliness, comfort and complementaryprovided facilities given by KFC and keeping the customers in such a clean appearance that the consumer was at home and satisfied when buying the KFC Grand Kota Bintang Bekasi.

2. The variable of reliability, it is known that reliability has had an effect on consumer satisfaction. The implication of his should be that the KFC Grand Kota Bintang Bekasi was always be able to provide adequate services so that the consumer would be satisfied with the KFC's service as expected.

3. Variable responsiveness, it is known that responsiveness has an effect on consumer satisfaction. The implication should be that KFC Grand Kota Bintang Bekasi has always to increase its employees' quick handling of the problem or the complaints of is consumers, so that the greater response given to KFC, consumer satisfaction would also increase.

\section{Suggestions}

1. For companies it is expected to be able to provide excellent quality of service in ministering to their consumers in order to win fast food and maintain or even increase the satisfaction of the consumers. Therefore, with this study it can be a reconsideration or a future evaluation so that companies will pay more attention and consider existing variables such as physical evidence, reliability and responsiveness primarily to collateral and empathy variables and thus increase consumer satisfaction.

2. For researchers it would be good if it used a different method or examined more factors that affected consumer satisfaction such as the quality of products, the pricing, the marketing strategies and so on. The suggestion is crucial to improving the accuracy of the research that will be obtained in the future. 


\section{REFERENCES}

[1] Arikunto, S. 2010. Prosedur penelitian suatu pendekatan praktik. Jakarta: PT Rineka Cipta

[2] Kharis, I.F. 2011. Studi mengenai impulse buying dalam penjualan online (Studi kasus di 12 lingkungan universitas diponegoro semarang). eprint.undip.ac.id: 1-29

[3] Kotler, Philip dan K.L.Keller. 2009. Manajemen Pemasaran. Edisi Keduabelas. PT Indeks, Jakarta

[4] Lupiyoadi. 2006. Manajemen Pemasaran Jasa: Teori dan Praktek. Jakarta: Salemba Empat

[5] Sugiyono. 2011. Metode Penelitian Pendidikan: Pendekatan Kuantitatif, Kualitatif dan R\&D. Bandung: Alfabeta 